\title{
Energy Balance and Reproduction on Dairy Cows Fed to Achieve Low or High Milk Production on a Pasture-Based System
}

\author{
M. Pedernera, ${ }^{* 1}$ S. C. García, ${ }^{*}$ A. Horagadoga, ${ }^{*}$ I. Barchia, $†$ and W. J. Fulkerson* \\ *M. C. Franklin Laboratory, University of Sydney, Camden, New South Wales, 2570, Australia \\ †Elizabeth Macarthur Agricultural Institute, Department of Primary Industries, Menangle New South Wales, 2568, Australia
}

\begin{abstract}
This study investigated the energy balance, metabolic changes, reproduction, and health in Australian Holstein-Friesian cows of average genetic merit fed to produce $6,000 \mathrm{~L}$ of milk/cow per lactation (restricted production; $\mathrm{Rp}$ ) on a predominantly grazed pasture diet, or $9,000 \mathrm{~L}$ of milk/cow per lactation (high production: $\mathrm{Hp}$ ) on a more intensive feeding regimen by using a partial mixed ration to supplement pasture. The mean $4 \%$ fat-corrected milk (FCM) and standard deviation achieved was $8,466 \pm 1,162 \mathrm{~L} / \mathrm{cow}$ per lactation for the Hp herd and 6,748 $\pm 787 \mathrm{~L} / \mathrm{cow}$ per lactation for the Rp herd. During early lactation, the degree of estimated negative energy balance was less in the Hp cows than in the Rp cows ( -16.1 vs. $-29.1 \mathrm{MJ} / \mathrm{cow}$ per day, respectively). Consequently, the mobilization of body reserves was also lower in the Hp cows, and this was reflected in lower concentrations of nonesterified fatty acids ( 0.70 vs. $0.84 \mathrm{mmol} / \mathrm{L})$ and B-hydroxybutyrate $(0.51$ vs. $0.69 \mathrm{mmol} / \mathrm{L}$ ) and greater concentrations of glucose (3.51 vs. $3.34 \mathrm{mmol} / \mathrm{L}$ ) and insulin-like growth factor-I (78.9 vs. $58.7 \mathrm{ng} / \mathrm{mL}$ ) for $\mathrm{Hp}$ and Rp cows, respectively. After calving, body condition score and body weight decreased to a similar extent in both herds and did not reflect the differences in mobilization of body reserves between the 2 herds. Reproductive performance was not significantly related to level of milk yield. The mean interval from calving to first active corpus luteum was $33(\mathrm{SD}=20) \mathrm{d}$ postpartum, and there were $1.4(\mathrm{SD}=$ 0.8 ) estrus cycles before the beginning of the breeding period ( $>50 \mathrm{~d}$ postpartum). The interval from calving to pregnancy was $114 \mathrm{~d}$, and the pregnancy rate after 12 wk of mating was $74 \%$. The number of cows with ovarian abnormalities was also similar between the 2 herds. Cows with a long postpartum anestrus had the lowest concentration of insulin-like growth factor-I. The number of health-related disorders was also similar between the herds, with the exception of mastitis,
\end{abstract}

Received February 13, 2008.

Accepted May 28, 2008.

${ }^{1}$ Corresponding author: mariana_pedernera@hotmail.com for which the incidence was significantly greater in the $\mathrm{Hp}$ cows. The results indicate that the production per cow could be increased from $6,748 \mathrm{~L}$ of $\mathrm{FCM} /$ cow per lactation for cows grazing pasture and supplemented with concentrates only at milking to $8,466 \mathrm{~L}$ of FCM/ cow per lactation, in one lactation, by supplementing pasture with a partial mixed ration. Despite the fact that production per cow increased substantially, the degree of estimated negative energy balance and the metabolic changes in early lactation were lower and reproductive performance was maintained.

Key words: milk production, energy balance, reproduction, pasture-based system

\section{INTRODUCTION}

On pasture based-systems of dairy farming such as those in Australia, a compact calving pattern in one (seasonal calving) or more (split calving) periods is required to maintain a high level of pasture utilization and hence minimize feed costs. However, a 12-mo calving interval is difficult to achieve because of the low fertility of the modern Holstein-Friesian (HF) dairy cow (Fulkerson et al., 2008). In fact, the fertility of the modern dairy cow has declined as milk production has increased over the past 2 decades (Lucy, 2001). Because intake potential has not kept up with the potential increase in milk production, an increasing proportion of energy needs to come from mobilization of body reserves, and this produces metabolic and endocrine changes that may affect fertility (Veerkamp et al., 2003). The mobilization of body reserves is even more extreme on pasture-based systems of farming. Kolver and Muller (1998) fed dairy cows of high genetic merit (producing $44 \mathrm{~L} /$ cow per day) a TMR in a shortterm experiment (4 wk). Cows fed the TMR achieved $40 \mathrm{~L} / \mathrm{cow}$ per day and cows grazing only high-quality pasture (ad libitum) achieved $30 \mathrm{~L} /$ cow per day. The lower milk yield of cows fed only pasture was mostly related to the lower DMI in that study and indicates, as also shown by Fulkerson et al. (2008), that cows of high genetic merit cannot achieve their genetic milk potential on pasture alone. The reasons for this are the greater energy expenditure in a grazed pasture 
Table 1. Mean ( $\left.{ }_{\mathrm{SD}} \mathrm{S}\right)$ diet composition (kg of DM/cow per day) and nutrient analysis (DM digestibility, CP, $\mathrm{NDF}, \mathrm{ADF}$, water-soluble carbohydrates, and ME) of the diet offered to cows to achieve either a low (Rp) or high $(\mathrm{Hp})$ level of milk production

\begin{tabular}{lcc}
\hline & \multicolumn{2}{c}{ Feeding system $^{1}$} \\
\cline { 2 - 3 } Item & $\mathrm{Rp}$ & $\mathrm{Hp}$ \\
\hline Diet composition (kg of DM/d) & & \\
Total DM offered & $20.4 \pm 3.4$ & $24.9 \pm 2.6$ \\
Pasture & $8.3 \pm 6.2$ & $5.2 \pm 4.3$ \\
Maize silage & $3.8 \pm 3.6$ & $6.1 \pm 1.8$ \\
Silage (lucerne or sorghum) & $1.6 \pm 3.2$ & $0.03 \pm 0.3$ \\
Hay (lucerne or oats) & $2.6 \pm 2.9$ & $3.7 \pm 1.4$ \\
Pellets & $3.8 \pm 1.6$ & $0.3 \pm 0.7$ \\
Wheat & $0.02 \pm 0.03$ & $0.02 \pm 0.02$ \\
Urea (g/d) & $0.01 \pm 0.01$ & $0.02 \pm 0.05$ \\
Limestone (g/d) & $69.3 \pm 0.1$ & $72.7 \pm 7.2$ \\
Nutrient analysis & $16.5 \pm 0.1$ & $17.5 \pm 0.1$ \\
DM digestibility (\% of DM) & $46.0 \pm 0.1$ & $37.4 \pm 0.1$ \\
CP (\% of DM) & $25.4 \pm 0.1$ & $20.5 \pm 0.2$ \\
NDF (\% of DM) & $0.1 \pm 0.1$ & $0.06 \pm 0.1$ \\
ADF (\% of DM) & $9.8 \pm 0.6$ & $10.3 \pm 0.3$ \\
Water-soluble carbohydrates (\% of DM) & & \\
ME (MJ/kg of DM) & & \\
\hline
\end{tabular}

${ }^{1} \mathrm{Hp}=$ high production; $\mathrm{Rp}=$ restricted production .

system, the lower intake capacity of the cows when fully fed on a bulky feed, and that cows are unable to maximize pasture utilization. Therefore, cows grazing pasture must be supplemented with energy-dense concentrates to achieve their genetic milk potential and to reduce the need to mobilize excessive amounts of body reserves in early lactation. However, the ability of more appropriate nutrition to reduce the mobilization of body reserves of dairy cows in early lactation, and its subsequent effect on reproductive performance and health, is equivocal. For example, the reproductive performance of dairy cows with similar genetic merit grazing pasture has been shown to be improved (Dillon et al., 1997; Fulkerson et al., 2001), remain unchanged (Logue et al., 1999; Buckley et al., 2000; Snijders et al., 2001; Kennedy et al., 2003), and become worse (McDougall et al., 1995) when supplemented with energy-dense supplements. Moreover, high milk yield per se had been associated with health problems, particularly mastitis (Ingvartsen et al., 2003). Therefore, the present study aimed to feed Australian HF cows of average genetic merit on a pasture-based system to achieve either a low (about 6,000 L/cow per lactation) or high (about 9,000 L/cow per lactation) level of milk production and evaluate the effects on energy balance, metabolite changes, reproductive performance, and health.

\section{MATERIALS AND METHODS}

The study was undertaken at Elizabeth Macarthur Agricultural Institute, Department of Primary Indus- tries, Menangle, New South Wales, Australia. The herd of 240 cows was predominantly $\mathrm{HF}$ and was divided randomly into 2 herds based on Australian breeding value for milk fat plus protein $(6.3 \mathrm{~kg} ; \mathrm{SD}=21.5)$, parity (3.6 lactations; $\mathrm{SD}=2.5$ ), and milk production in the previous lactation $(5,698 \mathrm{~L} / \mathrm{cow}$ per lactation; $\mathrm{SD}=$ 882). Within each herd, 39 cows were selected, based on their calving date (early autumn and winter), to be intensively monitored ("intensively monitored herd").

\section{Feed and Pasture Management}

Cows were grazed on pasture and supplemented with maize (Zea mays) silage until 3 wk before calving and on lucerne (Medicago sativa L.) hay, maize silage, and transition cow pellets from then until calving to meet their nutrient requirements (Standing Committee on Agriculture, 1990). After calving, the cows were assigned to a restricted-production $(\mathbf{R} \mathbf{p})$ herd, in which the cows were fed sufficient ME and CP to produce approximately 6,000 L/lactation or a high-production (Hp) herd, in which the cows were fed to produce approximately 9,000 L/lactation (Table 1).

The $\mathrm{Rp}$ cows received their entire concentrate allocation twice a day at milking, whereas the $\mathrm{Hp}$ cows received less than $4 \mathrm{~kg} / \mathrm{cow}$ per day at milking and the rest was mixed with the forage supplement as a partial mixed ration (PMR). The total ration offered was formulated to provide approximately 250 and $200 \mathrm{MJ}$ of $\mathrm{ME} /$ cow per day and a minimum of 17.5 and $16.5 \% \mathrm{CP}$ for the $\mathrm{Hp}$ and Rp herds, respectively. 
The pastures offered were kikuyu grass (Pennisetum clandestinum Hochst. ex Chiov.), oversown with short-rotation ryegrass (Lolium multiflorum Lam.) in autumn, and perennial ryegrass (Lolium perenne L.) and white clover (Trifolium repens L.). The pasture available to both herds was limited because of drought during the experimental period; therefore, in some months (mainly from mid-May to July), conserved forages [maize silage, lucerne hay, and oat (Avena sativa L.) hay] were fed instead of pasture. The herds were grazed in accordance with the best practice of using pasture on offer and leaf stage as the criterion to flag time to graze (Fulkerson and Donaghy, 2001). Pasture mass was estimated pre- and postgrazing by using an automatic rising plate meter (Farmworks, Feilding, New Zealand) calibrated to pasture type (García et al., 2007). Herbage, PMR, and dairy pellet samples were taken fortnightly for nutrient analysis (DM, NDF, $\mathrm{ADF}, \mathrm{CP}, \mathrm{ME}$, water-soluble carbohydrates, and ash) as described by García et al. (2007). Pasture samples were taken to simulate grazing height.

\section{Animal Measurements and Samples}

The experiment was conducted with the approval of the Animal Ethics Committee of New South Wales, Department of Primary Industries. Milk yield was recorded twice daily by using automatic flow meters (DeLaval, Tumba, Sweden). Milk samples were taken fortnightly at the a.m. and p.m. milking and were analyzed for milk fat, milk protein, and SCC by a MilkoScan instrument (Foss Electric, Hillerød, Denmark). The milk yield was corrected to $4 \%$ milk fat content (FCM) to compare milk yield between herds with different milk compositions. Body weight was recorded at weekly intervals, immediately after the a.m. milking, with an electronic cattle scale, and BCS (scale 1 to 8) was visually recorded monthly by the same observer.

In the intensively monitored herd ( $\mathrm{n}=78 \mathrm{cows})$, blood samples were taken weekly, immediately after the a.m. milking, from calving until $63 \mathrm{~d}$ postpartum. Samples were taken via coccygeal venipuncture into 3 evacuated tubes 1) containing heparin as anticoagulant for analysis of NEFA, BHBA, and urea; 2) without anticoagulant for analysis of IGF-I; or 3) with sodium fluoride and potassium oxalate as a glycolytic inhibitor for analysis of glucose. Samples with anticoagulant were placed on ice immediately after collection, whereas serum samples were kept at room temperature until the clot was formed. The samples were centrifuged at 1,000 $\times g$ to separate plasma and serum and were frozen at $-20^{\circ} \mathrm{C}$. Samples were later analyzed for NEFA, BHBA, glucose, and urea concentrations in plasma by enzy- matic colorimetry with an autoanalyzer (Veterinary Clinic, University of Sydney, Camden, Australia) and for IGF-I by using the ELISA technique (nonextraction IGF-I ELISA, DSL-10-2088, Diagnostic Systems Laboratories Inc., Webster, TX).

Milk yield and milk composition were measured as stated before. However, because milk composition was measured fortnightly, during the first 9 wk of lactation the milk composition in odd weeks was averaged to calculate the milk composition of even weeks. Foremilk samples were taken from one quarter of each cow 3 times per week during the p.m. milking from calving until $120 \mathrm{~d}$ postpartum, split into 4 aliquots, and frozen at $-20^{\circ} \mathrm{C}$ until analyzed. Milk acetone concentration was determined on these individual cow samples from calving until $63 \mathrm{~d}$ in lactation by flow injection analysis (Chemistry Department, La Trobe University, Victoria, Australia) as described by Marstorp et al. (1983). Milk samples were analyzed without any pretreatment; thus, only acetone content was measured. Milk progesterone concentration was also determined on these individual cow samples from calving until 120 d of lactation by RIA (Veterinary Progesterone RIA, Coated Tube RIA test, Orion Diagnostica, Espoo, Finland). Energy balance (MJ/cow per day) was estimated by using a prediction model $(\mathrm{r}=-0.64, P<0.001)$ based on acetone content in milk developed in our laboratory (Clark et al., 2005):

\section{Estimated energy balance (MJ/cow per day $)=$ $23.9-513 \times$ milk acetone $(\mathrm{mmol} / \mathrm{L})$.}

\section{Reproductive Management, Reproductive Performance, and Health Evaluation}

The herd had a split calving system with 2 mating periods: autumn-winter (May, June, and July) and spring-summer (October, November, and December). After calving, cows had a voluntary waiting period of $50 \mathrm{~d}$ before being artificially inseminated by the same trained operator. Estrus was detected by observation of estrus behavior at the time of milking (twice a day from calving) and by using tail paint or heat mount detectors (Kamar Heatmount Detectors, Kamar Inc., Steamboat Springs, CO). If cows were not pregnant by $120 \mathrm{~d}$ of lactation and were still within the breeding period, they received hormonal treatment to synchronize their estrus cycles. Cows with retained placenta or metritis were treated with antibiotics, and a single dose of prostaglandin was also administered to cows with retained placenta. Pregnancy was diagnosed by an experienced veterinarian by rectal palpation at least 6 wk after the last AI. 
Reproductive performance was evaluated by using submission rate (percentage of cows submitted for AI for the first time in the first $24 \mathrm{~d}$ of the breeding period), pregnancy rate (percentage of cows pregnant in relation to the number of cows mated), pregnancy rate to first $\mathrm{AI}(\%)$, calving to first $\mathrm{AI}$ (days), calving to pregnancy (days), and the 200-d not-in-calf rate (percentage of cows not pregnant by $200 \mathrm{~d}$ postpartum). Eight cows from the Hp group and 5 from the Rp group were culled and not inseminated, and were thus not included in the analysis. From the intensively monitored herds, commencement of cycling was defined when milk progesterone concentration was higher than $3 \mathrm{ng} /$ $\mathrm{mL}$ for more than 3 consecutive samples. The number of estrus cycles during the first $120 \mathrm{~d}$ postpartum and the pregnancy status were also determined by using progesterone concentration. Ovarian abnormalities were classified according to the criteria of Lamming and Darwash (1998).

The health status of the Rp and Hp herds was evaluated by comparing the incidence of clinical diseases during lactation. Cows used in the analysis were those lactating from February 2005 until January 2006, excluding 60 first-lactation cows. The epidemiological measures used were 1) incidence rate: number of cases (of clinical disease) presented in the determined period divided by the number of cows present during the same period; and 2) risk factors for the presentation of a disease: odds ratio (probability of occurrence of a disease). The repeatability of cases (the same cow having more than one case of a disease during the measured period) was $13.5 \%$ in the Hp cows and $7.8 \%$ in the Rp cows. The clinical diseases identified were mastitis (including subclinical mastitis, diagnosed by SCC); lameness (all locomotor disorders); parturient paresis (milk fever); retained fetal membranes; respiratory problems; 3-d sickness (bovine ephemeral fever), and other problems (nondiagnostic disorders that were manifested by a change in behavior, a substantial decrease in milk yield, or both).

\section{Statistical Analysis}

Milk Traits, Estimated Energy Balance, and Metabolic Changes. Mixed models of fixed and random terms with repeated measures were used to evaluate the data from both data sets with 240 or 78 cows. The variance-covariance structure between times was assumed to have a first-order autoregressive correlation [AR(1)]. Initially, we considered the following fully mathematical model: data = fixed (feeding system + time + lactation + calving season + genetic merit + all interactions $)+$ random (cow $\times$ time + error $)$, where fixed term denotes terms that have fixed effects, random term denotes terms that have random effects, feeding system has 2 levels ( $\mathrm{Hp}$ or Rp), time is a weekly observation, lactation denotes a cow with 2 or more lactations, calving season has 2 levels (spring or winter), and genetic merit has 4 levels based on the Australian breeding value for milk fat plus protein yield: high ( $\geq 31$ $\mathrm{kg})$, medium-high $(\geq 12.9 \mathrm{~kg})$, medium-low $(\geq-2.1 \mathrm{~kg})$, and low $(<-22.9 \mathrm{~kg})$.

Through the process of elimination for negligible effects, the terms in the model above could be reduced for different variables. Before the analysis, the normal distribution of variables was assessed and data were transformed (log or square root) when necessary. The restricted maximum likelihood technique (Littell et al., 1998) was used to estimate all parameters. Pearson correlation analysis was used to relate estimated energy balance to metabolic changes and milk traits. Further analysis was carried out to include "ovulation rank" in the model above. Ovulation rank was defined based on the commencement of ovarian activity: early resumption ( $<30 \mathrm{~d}$ postpartum), medium resumption (between 30 and $45 \mathrm{~d}$ postpartum), or late resumption (>45 d postpartum), based on Lucy et al. (1992).

Ovarian Activity and Health Traits. Mixed models such as the model above were also considered in the analysis of ovarian activity data ( $\mathrm{n}=78$ cows), but the time effect and the variance-covariance structure were absent. Furthermore, ovarian abnormalities ( $\mathrm{n}=$ 78 cows) and clinical manifestation of diseases $(n=240$ cows) were analyzed by using a binary data analysis, in which a generalized linear model was fitted to test the effect of feeding system. Experimental errors were assumed to follow a binomial distribution (McCullagh and Nelder, 1989).

\section{RESULTS}

\section{Lactation Performance ( $n=240$ cows)}

The mean lactation performance of the $\mathrm{Hp}$ and $\mathrm{Rp}$ cows is shown in Table 2. The Hp cows increased milk yield per lactation by $38 \%$ from the previous lactation milk production, whereas the Rp cows increased milk yield by $8 \%$. The Hp cows had greater $(P=0.04)$ milk protein content but lower $(P=0.03)$ milk fat content than the Rp cows; therefore, the milk fat and protein yields were 23 and $34 \%$ greater $(P<0.001)$ in the Hp and $\mathrm{Rp}$ cows, respectively.

\section{Early-Lactation Performance ( $n=78$ cows)}

In early lactation, milk yield and milk composition were significantly different $(P<0.05)$ between herds (Figure 1). Milk yield from the Hp cows peaked at 34.9 
Table 2. Mean yield of milk (L/cow per lactation) and milk components (kg/cow per lactation), and content (\%) of milk components among cows fed to achieve either a low $(\mathrm{Rp})$ or high $(\mathrm{Hp})$ level of milk production $(\mathrm{n}=240 \mathrm{cows})$

\begin{tabular}{|c|c|c|c|c|}
\hline \multirow[b]{2}{*}{ Item } & \multicolumn{2}{|c|}{ Feeding system $^{1}$} & \multirow[b]{2}{*}{$\mathrm{SED}^{2}$} & \multirow[b]{2}{*}{$P$-value } \\
\hline & $\mathrm{Rp}$ & $\mathrm{Hp}$ & & \\
\hline Milk yield (L/cow per lactation) & 6,353 & 8,181 & 248 & $<0.001$ \\
\hline FCM yield $^{3}$ (L/cow per lactation) & 6,748 & 8,466 & 246 & $<0.001$ \\
\hline Milk fat content (\%) & 4.39 & 4.23 & 0.01 & 0.037 \\
\hline Milk protein content (\%) & 3.11 & 3.20 & 0.05 & 0.042 \\
\hline
\end{tabular}

${ }^{1} \mathrm{Hp}=$ high production; $\mathrm{Rp}=$ restricted production.

${ }^{2} \mathrm{SED}=$ standard error of the difference.

${ }^{3}$ Fat-corrected milk yield (4\%).

$\mathrm{L}$ of $\mathrm{FCM} /$ cow per day at approximately 7 wk postpartum, whereas milk yield for the Rp cows was $29.6 \mathrm{~L}$ of $\mathrm{FCM} /$ cow per day at approximately 4 wk postpartum. Despite the differences in milk yield at peak lactation, the mean daily FCM yield from calving to 9 wk postpartum was only approximately $4 \mathrm{~L}$ greater $(P<0.001)$ in the Hp cows (Figure 1b). Milk protein content was similar $(P>0.05)$ between the herds, reaching its nadir at 5 wk of lactation and then rising slowly until $9 \mathrm{wk}$ of lactation (Figure 1c). Milk fat content decreased in both herds until 9 wk of lactation, but the rate of decline was slightly faster in the $\mathrm{Hp}$ cows than in the $\mathrm{Rp}$ cows (Figure 1d). Both milk protein yield (Figure 1e) and milk fat yield (Figure 1f) were greater $(P<0.05)$ in the Hp cows than in the Rp cows from wk 4 to 9 postpartum.

\section{Energy Balance and Metabolic Changes ( $n=78$ cows)}

The BW and BCS decreased similarly in early lactation in both herds $(P>0.05)$. The Hp cows lost 0.56 units of BCS and $17.9 \mathrm{~kg}$ of BW, and the Rp cows lost 0.67 units of BCS and $23.9 \mathrm{~kg}$ of BW from calving to 9 wk postpartum. Mean estimated energy balance during the first $9 \mathrm{wk}$ postpartum was significantly less negative $(P<0.001)$ in the Hp cows than in the Rp cows (Figure 2); the nadir of estimated negative energy balance (NEB) was $-28 \mathrm{MJ} / \mathrm{cow}$ at 2 wk postpartum in the $\mathrm{Hp}$ cows compared with $-47 \mathrm{MJ} /$ cow at $3 \mathrm{wk}$ postpartum in the Rp cows. The changes in metabolites in circulation in cows in early lactation, and their interactions with feeding system and week postpartum are shown in Figure 3.

The changes in NEFA concentration indicated that both herds of cows had to rely on mobilization of body reserves to satisfy the nutrient demand for milk production, particularly in the first 2 wk postpartum (Figure 3a). However, the concentrations of NEFA and BHBA were lower $(P<0.01)$ in the Hp cows than in the Rp cows, reflecting a lower degree of fat reserve mobilization in the former (Figure 3b). The glucose concentration was within the normal range in both herds but was significantly greater $(P<0.05)$ in the $\mathrm{Hp}$ cows compared with the Rp cows from 3 to 5 wk postpartum (Figure 3c). In the Hp cows, the concentration of IGF-I increased from calving until 9 wk postpartum and was always significantly greater $(P<0.001)$ than in the Rp cows from wk 2 postpartum. The Rp cows had an almost constant $(P>0.05)$ concentration of IGF-I for the same period (Figure 3d).

The mean concentration of urea was within the normal range but was significantly greater $(P<0.001)$ in $\mathrm{Hp}$ cows than in Rp cows $(7.2$ and $5 \mathrm{mmol} / \mathrm{L}$, respectively), as expected from the diet composition (data not shown). The effect of genetic merit was not significant $(P>0.05)$ for any of the metabolites measured. The season of calving did not affect concentrations of the metabolites measured, except that IGF-I concentration was greater $(P<0.001)$ in cows calving in early autumn than in cows calving in winter $(80.2$ vs. $58.7 \mathrm{ng} / \mathrm{mL}$, respectively). When the estimated energy balance was related to other blood metabolites that reflect the mobilization of body reserves, the estimated energy balance was negatively correlated with NEFA ( $\mathrm{r}=-0.38 ; P<$ $0.001)$ and BHBA $(\mathrm{r}=-0.64 ; P<0.001)$ and positively correlated with glucose $(\mathrm{r}=0.30 ; P<0.001)$, IGF-I ( $\mathrm{r}=$ $0.34 ; P<0.001)$, and urea $(\mathrm{r}=0.19 ; P<0.001)$.

\section{Reproduction and Health}

The pregnancy rate was not significantly different $(P$ $>0.05$ ) between $\mathrm{Hp}$ cows and Rp cows; $72.1 \%$ of the Hp cows and $77.1 \%$ of the Rp cows were pregnant after 12 
wk of mating. The mean time from calving to the first AI was $83 \mathrm{~d}(\mathrm{SD}=31 \mathrm{~d})$ and the period from calving to conception was $114 \mathrm{~d}(\mathrm{SD}=53 \mathrm{~d})$, and this was not significantly different $(P>0.05)$ between the herds. The percentage of cows submitted to $\mathrm{AI}$ in the first $50 \mathrm{~d}$ of the breeding period was similar $(P>0.05 ; 64 \%$ for $\mathrm{Hp}$ cows and $72 \%$ for $\mathrm{Rp}$ cows). The pregnancy rate to the first AI was 49 and 53\% $(P>0.05)$ for Hp and Rp cows, respectively. In both herds, only $6.5 \%$ of cows remained not pregnant at $200 \mathrm{~d}$ after calving $(P>0.05)$.

The ovarian activity was similar $(P>0.05)$ for both the Hp and Rp cows (Table 3). Ovarian abnormalities were present in $49 \%$ of the cows, and this was similar $(P>0.05)$ between herds. The most frequent abnormalities were long postpartum anestrus and long interovulation intervals. Season of calving affected the day
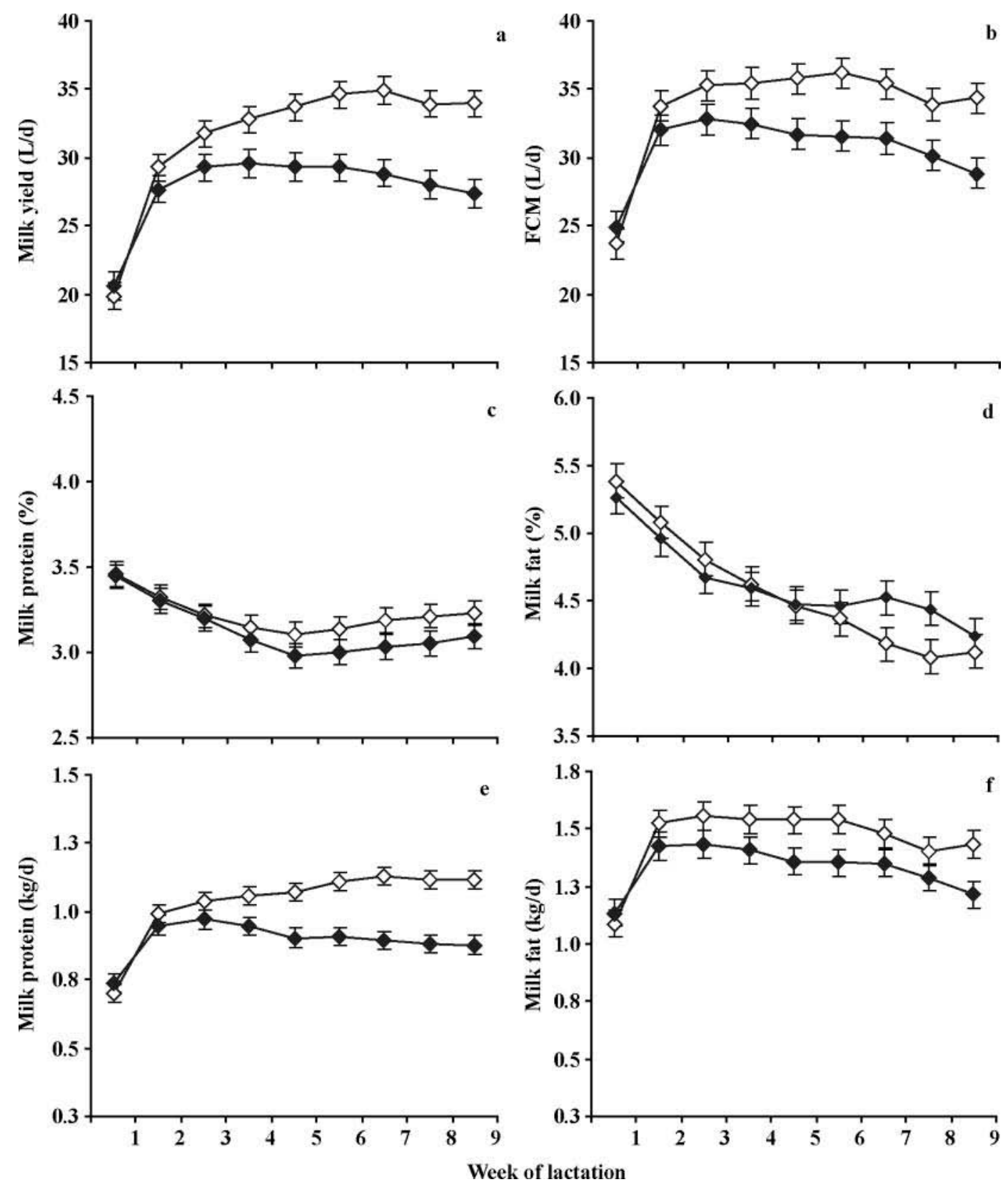

Figure 1. Milk yield (L/cow per day; a), FCM yield (L/cow per day; b), milk protein content (\%; c), milk fat content (\%; d), milk protein yield (kg/cow per day; e), and milk fat yield (kg/cow per day; f) in early-lactating cows fed to achieve either a low $(\downarrow)$ or high $(\diamond)$ level of milk production ( $\mathrm{n}=78 \mathrm{cows})$. Vertical bars indicate standard error of the mean. 


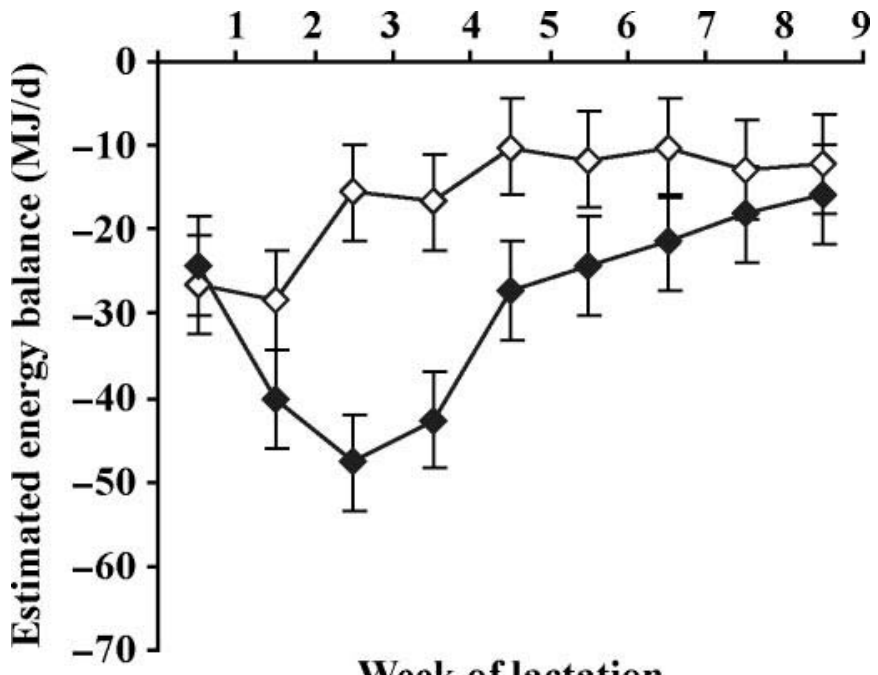

\section{Week of lactation}

Figure 2. Energy balance (MJ/cow per day) in early-lactating cows fed to achieve either a low $(\downarrow)$ or high $(\diamond)$ level of milk production $(\mathrm{n}=$ 78 cows). Vertical bars indicate standard error of the mean. to commencement of ovarian activity; cows calving in autumn commenced ovarian activity earlier $(P=0.07)$ than cows calving in winter ( $28 \mathrm{vs} .37 \mathrm{~d}$, respectively).

The relationship between time to commencement of ovarian activity and energy balance indicators and milk production was evaluated for both herds together because there was no significant difference in reproductive performance between the Hp and Rp cows, but the herd effect was kept in the mathematical model (Table 4).

Overall, $45 \%$ of cows commenced ovarian activity within $30 \mathrm{~d}$ of calving, $32 \%$ commenced between 30 to $45 \mathrm{~d}$ postpartum, and $23 \%$ commenced at more than 45 d postpartum. Although not significantly different $(P>$ 0.05 ) between feeding systems, the percentage of cows with early resumption was 51 and $38 \%$, the percentage with medium resumption was 28 and $36 \%$, and the percentage with late resumption was 21 and $26 \%$ for $\mathrm{Hp}$ and Rp cows, respectively. The time to commencement of ovarian activity was not significantly $(P>$ $0.05)$ related to milk traits in the first 9 wk of lactation. Estimated energy balance and energy balance indicators were also not significantly $(P>0.05)$ related to the
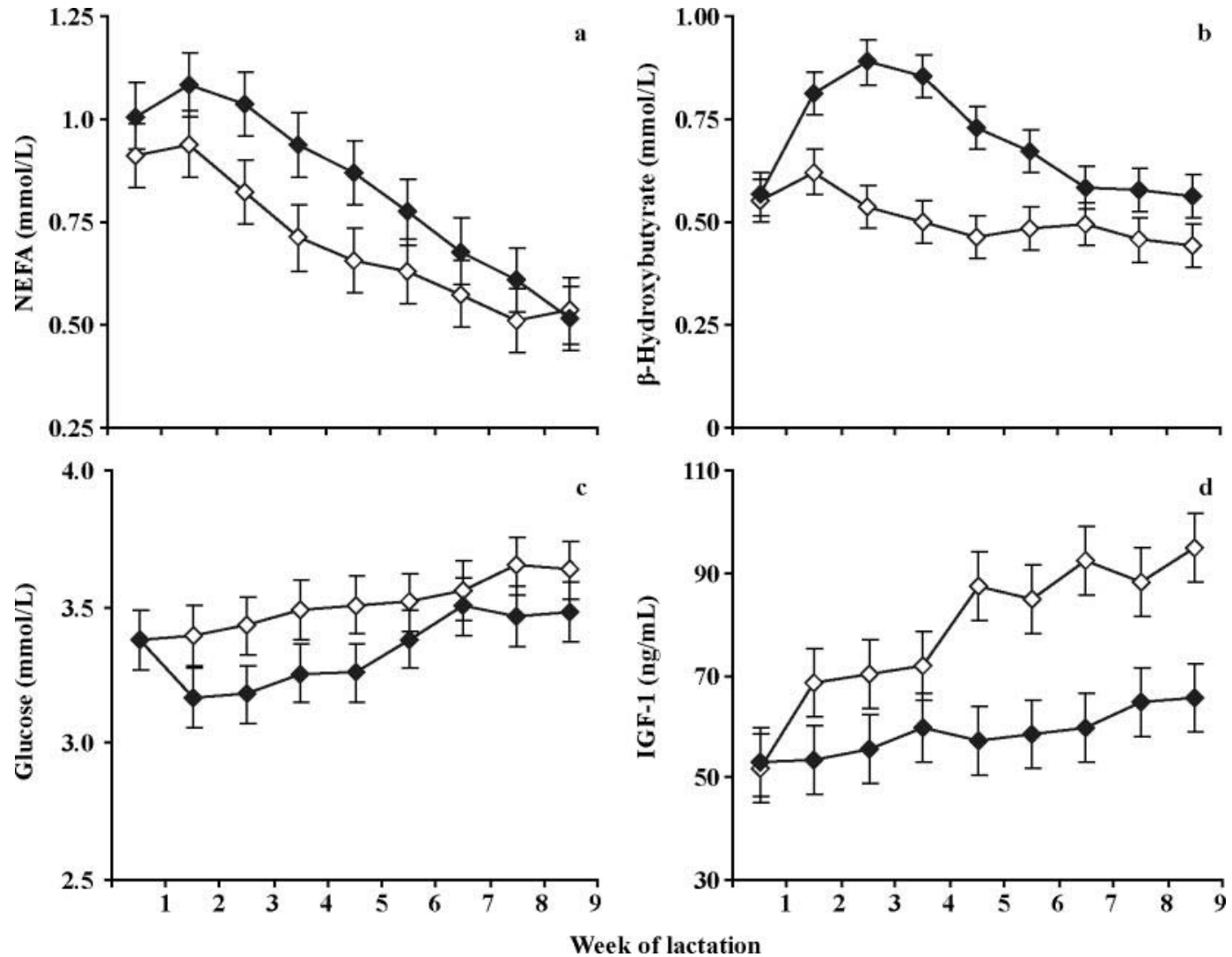

Figure 3. Nonesterified fatty acids (mmol/L; a), BHBA (mmol/L; b), glucose (mmol/L; c), and IGF-I (ng/mL; d) concentrations in earlylactating cows fed to achieve either a low $(\diamond)$ or high $(\diamond)$ level of milk production $(n=78$ cows). Vertical bars indicate standard error of the mean. 
Table 3. Effect on ovarian activity (mean $\pm \mathrm{SD}$ ) and atypical ovarian patterns in the first $120 \mathrm{~d}$ of lactation when cows are fed to achieve either a low $(\mathrm{Rp})$ or high $(\mathrm{Hp})$ level of milk production $(\mathrm{n}=78$ cows)

\begin{tabular}{|c|c|c|c|}
\hline \multirow[b]{2}{*}{ Item } & \multicolumn{2}{|c|}{ Feeding system ${ }^{1}$} & \multirow[b]{2}{*}{$P$-value } \\
\hline & $\mathrm{Rp}$ & $\mathrm{Hp}$ & \\
\hline \multicolumn{4}{|l|}{ Ovarian activity } \\
\hline Days to first luteal phase & $32 \pm 17$ & $33 \pm 23$ & 0.904 \\
\hline Luteal phases before start breeding (n) & $1.4 \pm 0.8$ & $1.4 \pm 0.8$ & 0.691 \\
\hline Luteal phases before 120 d postpartum (n) & $3.7 \pm 1.3$ & $3.5 \pm 1.5$ & 0.8 \\
\hline Days to first AI & $88 \pm 27$ & $83 \pm 29$ & 0.751 \\
\hline Normal ovarian pattern & 20 & 19 & 0.642 \\
\hline Long anestrus postpartum & 10 & 9 & 0.792 \\
\hline Long interovulation interval & 5 & 8 & 0.36 \\
\hline Delayed luteolysis during the first estrus cycle & 0 & 2 & 0.992 \\
\hline Delayed luteolysis during subsequent estrus cycles & 1 & 1 & 0.891 \\
\hline Embryo mortality & 3 & 0 & 0.571 \\
\hline
\end{tabular}

${ }^{1} \mathrm{Hp}=$ high production; $\mathrm{Rp}=$ restricted production .

time to commencement of ovarian activity, except for IGF-I concentration, which was significantly lower $(P$ $<0.001$ ) in cows with late resumption compared with early or medium resumption.

Mastitis and lameness were the most prevalent problems in both herds, and mastitis was significantly different $(P<0.05)$ between herds. The incidence rate of mastitis was 0.15 for the Hp herd and 0.10 for the Rp herd. The risk of presenting (odds ratio) any health disorder was not significantly different between herds $(P>0.05)$, except for mastitis. The $\mathrm{Hp}$ cows were 2 times more likely to have mastitis than the Rp cows (odds ratio $=2.07$, confidence interval $=1.16$ to $3.69, P$ $<0.05)$.

\section{DISCUSSION}

This study demonstrates that energy balance could be improved and fluctuations in key metabolites could be reduced when Australian HF cows of average genetic merit were fed to increase milk yield from a level of 5,945 L/cow per lactation when fed in a typical grazed pasture system (pasture plus concentrates at milking) to $8,466 \mathrm{~L}$ of $\mathrm{FCM} / \mathrm{cow}$ per lactation (SD $=1,162 \mathrm{~L}$ ) when cows were also supplemented with a PMR. The $30 \%$ increase in milk production had no affect on reproductive performance, but the incidence of mastitis was increased.

In previous studies, a negative effect of milk yield on fertility was found in cows of similar and different genetic merit. Lean et al. (1989) analyzed a data set of 3,850 lactations of cows in Tulare, California, producing on average $8,661 \mathrm{~L}$ of milk/cow per lactation and found that cows with high peak milk yields $(>38.2 \mathrm{~L} /$ cow per day) had lower conception rates to the first and second breeding (or mating) and had more days from calving to pregnancy (approximately $10 \mathrm{~d}$ more) than lower producing cows. Fonseca et al. (1983) studied 212 $\mathrm{HF}$ and Jersey cows for an entire lactation and found that the number of days from calving to first breeding increased by $2.1 \mathrm{~d}$ for each $100 \mathrm{~kg}$ of milk increase in the first $70 \mathrm{~d}$ of lactation. The number of days from

Table 4. Effect on milk traits, energy balance, and energy balance indicators when cows are subclassified based on time to commencement of ovarian activity (days postpartum) in the intensively monitored herd in early lactation ( $\mathrm{n}=78 \mathrm{cows})$

\begin{tabular}{|c|c|c|c|c|c|}
\hline Item & $\begin{array}{c}\text { Early } \\
\text { resumption } \\
(<30 \mathrm{~d})\end{array}$ & $\begin{array}{l}\text { Medium } \\
\text { resumption } \\
\text { (30 to } 45 \mathrm{~d})\end{array}$ & $\begin{array}{l}\text { Late } \\
\text { resumption }(>45 \mathrm{~d})\end{array}$ & $\mathrm{SED}^{1}$ & $P$-value \\
\hline Milk yield (L/cow per day) & 29.8 & 29.5 & 28.1 & 1.12 & 0.786 \\
\hline Milk protein content (\%) & 3.14 & 3.17 & 3.11 & 0.10 & 0.139 \\
\hline Milk fat content (\%) & 4.61 & 4.51 & 4.61 & 0.19 & 0.750 \\
\hline Estimated energy balance (MJ/cow per day) & -19.0 & -24.9 & -25.2 & 3.99 & 0.060 \\
\hline Glucose (mmol/L) & 3.42 & 3.44 & 3.42 & 0.07 & 0.719 \\
\hline IGF-1 (ng/mL) & 70.3 & 75.9 & 62.2 & 6.31 & $<0.001$ \\
\hline
\end{tabular}

${ }^{1} \mathrm{SED}=$ standard error of the difference. 
calving to pregnancy was also greater as milk yield increased, but only in Jersey cows. Recently, Kawashima et al. (2007) showed that the rate of increase in milk yield, from $1 \mathrm{wk}$ postpartum to peak milk yield, is the factor affecting the time to commencement of ovarian activity, rather the milk yield achieved at the peak of lactation.

In studies in cows with different genetic merit, Harrison et al. (1990) found that cows of high genetic merit producing $10,814 \mathrm{~L} / \mathrm{cow}$ per lactation had less intense manifestations of estrus, and this was probably one factor in the longer calving intervals compared with cows of low genetic merit producing $6,912 \mathrm{~L} /$ cow per lactation. More recently, Fulkerson et al. (2001) found that HF cows of high genetic merit had a calving-topregnancy interval $21 \mathrm{~d}$ longer than cows of lower genetic merit in a pasture-based dairy system. Similarly, Dillon et al. (2003) found that Dutch HF cows, producing on average $27.6 \mathrm{~L} / \mathrm{cow}$ per day at first insemination, had lower reproductive performance than other breeds producing less milk (25.6, 24.3, and $21.3 \mathrm{~L} / \mathrm{cow}$ per day for Irish HF, French Montbeliarde, and French Normande, respectively).

These studies indicate a negative relationship between reproductive performance and milk yield, and this relationship appears to be true whether high milk yield has been achieved by improved management or by genetic gain. However, the more likely reason for the reduced fertility appears to be the greater need for high-producing cows to rely on body reserves to overcome the greater energy requirements, which exacerbates the changes in metabolic and hormonal factors during early lactation (Butler, 2003; Veerkamp et al., 2003). This negative relationship $(r=-0.80)$ between milk yield and energy balance has been shown previously (Butler and Smith, 1989) and has been proven to be independent of genetic merit (Knight et al., 2004). The milk yield of cows of high or low genetic merit (with milk yield artificially increased by frequent milking, bovine somatotropin, or thyroxin administration) was associated with increased mobilization of body reserves (Knight et al., 2004).

In contrast, in the present study using Australian $\mathrm{HF}$ cows of average genetic merit, no significant negative relationship was found between milk yield and reproductive performance, but this was presumably due to an increase in energy availability to meet the extra requirements of $\mathrm{Hp}$ cows during early lactation. However, despite the improvement in estimated energy balance, the reproductive performance was not improved. However, this result should be treated with caution because reproductive performance was based on on-farm data (e.g., pregnancy rate); therefore, the number of cows used might not show a significant effect. However, when using milk progesterone concentration, which measures ovarian activity independently of management factors, the $\mathrm{Hp}$ and Rp cows had similar ovarian activity despite the significant differences in milk yield and estimated energy balance. Moreover, this result agrees with the study of Logue et al. (1999), who also found that a greater level of energy supplementation (cows supplemented with $5.5 \mathrm{~kg} / \mathrm{cow}$ per day rather than $1.4 \mathrm{~kg} / \mathrm{cow}$ per day of concentrates) fed to reduce the mobilization of body reserves did not affect fertility. In that study, cows of high genetic merit produced 8,707 or $6,014 \mathrm{~L} / \mathrm{cow}$ per lactation, respectively, when fed high or low levels of concentrate, and these milk yields were similar to the levels of milk production in our study. Ferris et al. (2002) also found no effect on fertility when multiparous cows of high genetic merit were fed a grass silage-based diet (winter feeding) supplemented with concentrates in early lactation. Increasing concentrates (up to $14 \mathrm{~kg} / \mathrm{cow}$ per day) in the diet reduced the body condition loss and lowered the extent and degree of NEB compared with cows supplemented with $5.5 \mathrm{~kg} / \mathrm{cow}$ per day of concentrates.

In contrast to these studies, Dillon et al. (1997) reported a reduction in the number of services per conception in cows grazing pasture and supplemented with $4 \mathrm{~kg}$ of concentrates/cow per day compared with nonsupplemented cows. Fulkerson et al. (2001) also found that increasing concentrates from approximately 1 to $6 \mathrm{~kg} / \mathrm{cow}$ per day to cows of either high or low genetic merit grazing kikuyu grass and ryegrass pastures significantly reduced the time from calving to commencement of ovarian activity. The difference between our results and those of Dillon et al. (1997) and Fulkerson et al. (2001) might be because the Rp cows in our study were less energy restricted. Although it was not possible to calculate the absolute level of energy restriction in these studies, our Rp cows were receiving a concentrate level similar to the highest level of concentrate fed in the other 2 studies. On average, in early lactation the Rp cows were fed to approximately $90 \%$ of their energy requirements (estimated by using actual milk production and energy offered in the diet), whereas the Hp cows were fed to $100 \%$ of energy requirements in relation to milk production achieved; therefore, differences in voluntary intake were predominantly affecting the level of energy intake of the cows. This explanation is supported by the results of Kennedy et al. (2003), who also found that when 5, 7, or $10 \mathrm{~kg}$ of concentrates/cow per day was fed to cows grazing pasture, reproductive performance did not differ between groups. Therefore, to maintain good reproductive performance, it is important to offer a diet to cover the energy requirements for the cow, but extra energy is unlikely to improve fertility. 
The changes in metabolites used as indicators of energy balance in the present study are in accordance with the homeorhetic changes found at the onset of lactation in other studies (Kennedy et al., 2003; Reist et al., 2003). However, in the Hp cows, these changes were less extreme than those in the Rp cows. Reist et al. (2003) found that NEFA, acetone, and BHBA concentrations in the plasma of HF cows decreased and that glucose increased over the first 10 wk postpartum when more energy was offered in the diet. Kennedy et al. (2003) did not find a feeding system effect on metabolite concentration, although in that study metabolites were measured only twice during the first $6 \mathrm{wk}$ of lactation and were not measured in the first $2 \mathrm{wk}$ of lactation, when major changes have been found (Beam and Butler, 1998; Clark et al., 2005; present study). The faster recovery of $\mathrm{Hp}$ cows from estimated NEB was also reflected in a more rapid increase in IGF-I in circulation, which has been shown to be significantly correlated with energy balance (Spicer et al., 1990; Clark et al., 2005; Patton et al., 2007). In previous studies (K. L. Macmillan, University of Melbourne, Australia; personal communication), high-producing cows tended to have lower IGF-I, and this was not related to genetic merit. However, in the present study we did not find that Hp cows had lower IGF-I. This controversy can be explained by the fact that IGF-I is affected by diet composition. Reist et al. (2003) found that IGF-I concentration in cows in early lactation increased rapidly if the cows were fed a high-energy diet. Despite the fact that the energy balance indicators used revealed significant differences in the mobilization of body reserves between herds, the changes in BW and BCS in Hp and Rp cows were similar. Buckley et al. (2000) compared the performance of HF cows of high and medium genetic merit at 3 different stocking rates and with levels of concentrate supplementation similar to ours (1.6 or $3.2 \mathrm{~kg} / \mathrm{cow}$ per day). They found reduced mobilization of body reserves at the greater level of supplementation (indicated by the lower concentration of NEFA in plasma), but they also found no differences in BW and BCS changes in the first $20 \mathrm{wk}$ of lactation. The reason might be that in early lactation, BW and BCS changes are poor indicators of energy balance, and this supports the conclusion of Clark et al. (2005). Sutter and Beever (2000) accurately measured energy changes (by using calorimetric chambers and energy losses in feces and urine) during the first $7 \mathrm{wk}$ of lactation and found that approximately $95 \mathrm{~kg}$ of tissue was mobilized, whereas BW loss (with BW measured 3 times per week) was approximately $43 \mathrm{~kg}$. Thus, although BW and BCS are practical indicators of energy status and should be measured, they do not accurately reflect the extent of mobilization of body reserves in early lactation.
Interestingly, despite the fact that the $\mathrm{Rp}$ cows had a greater degree and duration of estimated NEB, and hence a greater level of mobilization of body reserves, their times to commencement of ovarian activity and overall reproductive performance were similar to those of the Hp cows. Other studies have also found that NEB did not influence the commencement of ovarian activity in HF cows with similar (Spicer et al., 1990) or different (Snijders et al., 2001) genetic merit. Although in the present study estimated energy balance was not related to reproductive performance, cows with a longer postpartum anestrus period ( $>45 \mathrm{~d}$ postpartum) had lower concentrations of IGF-I than cows that started cycling earlier. This agrees with the results of studies by Beam and Butler (1998) and Butler (2003), which showed that IGF-I is negatively associated with the time to commencement of ovarian activity because of its capacity to stop ovulation of the first dominant follicle by reducing the response to LH. Moreover, Spicer et al. (1990) found that cows with a longer duration of NEB had a lower concentration of IGF-I and a slower recovery postpartum. Similarly, Patton et al. (2007) found that cows with more extreme NEB and low DMI had also lower IGF-I in the first 2 wk of lactation. However, in the present study the other indicators of energy balance (NEFA, BHBA, and glucose) were not related to time of commencement of ovarian activity. Similarly, Ferris et al. (2002) observed that these metabolites (mean concentration in $52 \mathrm{~d}$ of lactation) were not related to whether cows start ovarian activity by $\mathrm{d}$ 45 of lactation. Thus, it might be that these indicators clearly reflect the changes in energy status in the short term, but not when taken as an average long term (e.g., mean at 9 wk postpartum). Thus, it is likely that concentration of IGF-I can be used as a long-term indicator of the energy balance status and can be used indirectly as an indication of cows likely to have long anestrous postpartum. This must be demonstrated, but there is already evidence that when insulin reaches a certain level (within the physiological range), it can regenerate the growth hormone-IGF-I axis by stimulating the growth hormone receptor and IGF-I gene expression, which normally is impaired because of the growth hormone resistance in early lactation caused by NEB (Butler et al., 2003).

Interestingly, the concentration of IGF-I was affected by calving season in our study, being lower in cows calving in winter than in early autumn. This contrasts to the findings of Spicer et al. (1990), who found that in cooler temperatures (average $3^{\circ} \mathrm{C}$ ) the IGF-I concentration is greater. In our study, the difference in mean daily temperature between seasons was not as extreme $\left(19\right.$ vs. $\left.12^{\circ} \mathrm{C}\right)$. Thus, it might be possible that the photoperiod is causing the variation in IGF-I concentration 
because it was found to rise in spring compared with in winter. Dahl et al. (2000) found that heifers exposed to $16 \mathrm{~h}$ of light and $8 \mathrm{~h}$ of darkness (to reduce melatonin secretion) had an increased concentration of IGF-I compared with heifers exposed to $16 \mathrm{~h}$ of darkness and $8 \mathrm{~h}$ of light.

The Hp cows had a greater incidence of mastitis. In agreement with this result, a meta-analysis of 53 studies by Dohoo et al. (2003) showed that administration of recombinant bST increased milk yield by $11.3 \%$ in primiparous cows and by $15.6 \%$ in multiparous cows, and also increased the risk of mastitis by $25 \%$. In a review of epidemiological studies, high milk yield $(>7,000 \mathrm{~L} /$ cow per lactation) was also found to increase the risk of mastitis (Ingvartsen et al., 2003), although the reason for the increased susceptibility to mastitis was not clear and may be related to an immune system deficiency or management issues (Ingvartsen et al., 2003). In the present study, however, the increase in the incidence of mastitis in Hp cows was likely to have been due to management factors associated with the increased intensity of feeding (feeding the PMR on a feed pad), and although the area was cleaned as frequently as possible, cows spent approximately $2 \mathrm{~h}$ there.

\section{CONCLUSIONS}

Milk production per cow among cows of average genetic merit managed on a typical pasture-based system was improved by $30 \%$ in one lactation when the intake of energy was increased by offering a PMR, and this led to an improvement in estimated energy balance and a reduction in the mobilization of body reserves in early lactation. This achievement was without an effect on the reproductive performance and health of the cows, except for an increase in the incidence of mastitis that was associated with management.

\section{ACKNOWLEDGMENTS}

The authors wish to acknowledge the staff at the Elizabeth Macarthur Agricultural Institute Farm for the management and care of the animals, and in particular, Terry Osborne, the farm manager. We are also grateful to Amy Rogers for the help in feed and milk data collection. The Consejo Nacional de Ciencia y Tecnologia (CONACYT), Mexico City, Mexico, is gratefully acknowledged for the scholarship to Mariana Pedernera, and FutureDairy (Camden, New South Wales, Australia) for the funding for this research project.

\section{REFERENCES}

Beam, S. W., and W. R. Butler. 1998. Energy balance, metabolic hormones, and early postpartum follicular development in dairy cows fed prilled lipid. J. Dairy Sci. 81:121-131.
Buckley, F., P. Dillon, M. Rath, and R. F. Veerkamp. 2000. The relationship between genetic merit and live weight, condition score, and energy balance of spring calving Holstein Friesian dairy cows on grass based systems of milk production. J. Dairy Sci. 83:1878-1886.

Butler, S. T., A. L. Marr, S. H. Pelton, R. P. Radcliff, M. C. Lucy, and W. R. Butler. 2003. Insulin restores $\mathrm{GH}$ responsiveness during lactation-induced negative energy balance in dairy cattle: Effects on expression of IGF-I and GH receptor 1A. J. Endocrinol. 176:205-217.

Butler, W. R. 2003. Energy balance relationships with follicular development, ovulation and fertility in postpartum dairy cows. Livest. Prod. Sci. 83:211-218.

Butler, W. R., and R. D. Smith. 1989. Interrelationship between energy balance and postpartum reproductive function in dairy cattle. J. Dairy Sci. 72:767-783.

Clark, C. E. F., W. J. Fulkerson, K. S. Nandra, I. Barchia, and K. L. MacMillan. 2005. The use of indicators to assess the degree of mobilization of body reserves in dairy cows in early lactation on a pasture-based diet. Livest. Prod. Sci. 94:199-211.

Dahl, G. E., B. A. Buchanan, and H. A. Tucker. 2000. Photoperiodic effects on dairy cattle: A review. J. Dairy Sci. 83:885-893.

Dillon, P., S. Crosse, and B. O’Brien. 1997. Effect of concentrate supplementation of grazing dairy cows in early lactation on milk production and milk processing quality. Ir. J. Agric. Food Res. 36:145-159.

Dillon, P., S. Snijders, F. Buckley, B. Harris, P. O'Connor, and J. F. Mee. 2003. A comparison of different dairy cow breeds on a seasonal grass-based system of milk production. 2. Reproduction and survival. Livest. Prod. Sci. 83:35-42.

Dohoo, I. R., K. E. Leslie, L. DesCoteaux, A. Fredeen, P. Dowling, A. Preston, and W. Shewfelt. 2003. A meta-analysis of the effects of recombinant bovine somatotropin. 2. Effects on animal health, reproductive performance, and culling. Can. J. Vet. Res. 67:252-264.

Ferris, C. P., M. A. McCoy, S. D. Lennox, D. C. Catney, and F. J. Gordon. 2002. Nutrient utilization and energy balance associated with two contrasting winter milk production systems for high genetic merit autumn calving dairy cows. Ir. J. Agric. Food Res. 41:55-70.

Fonseca, F. A., J. H. Britt, B. T. McDaniel, J. C. Wilk, and A. H. Rakes. 1983. Reproductive traits of Holstein and Jerseys. Effects of age, milk yield, and clinical abnormalities on involution of cervix and uterus, ovulation, estrus cycles, detection of estrus, conception rate, and days open. J. Dairy Sci. 66:1128-1147.

Fulkerson, W. J., T. M. Davison, S. C. Garcia, G. Hough, M. E. Goddard, R. Dobos, and M. Blockey. 2008. Holstein-Friesian dairy cows under a predominantly grazing system: Interaction between genotype and environment. J. Dairy Sci. 91:826-839.

Fulkerson, W. J., and D. J. Donaghy. 2001. Plant-soluble carbohydrate reserves and senescence-Key criteria for developing an effective grazing management system for ryegrass-based pastures: A review. Aust. J. Exp. Agric. 41:261-275.

Fulkerson, W. J., J. Wilkins, R. C. Dobos, G. M. Hough, M. E. Goddard, and T. Davison. 2001. Reproductive performance in Holstein-Friesian cows in relation to genetic merit and level of feeding when grazing pasture. Br. Soc. Anim. Sci. 73:397-406.

García, S. C., M. Pedernera, W. J. Fulkerson, A. Horadagoda, and K. S. Nandra. 2007. Feeding concentrates based on individual cow requirements improves the yield of milk solids in dairy cows grazing restricted pasture. Aust. J. Exp. Agric. 47:502-508.

Harrison, R. O., S. P. Ford, J. W. Young, A. J. Conley, and A. E. Freeman. 1990. Increased milk production versus reproductive and energy status of high producing dairy cows. J. Dairy Sci. 73:2749-2758.

Ingvartsen, K. L., R. J. Dewhurst, and N. C. Friggens. 2003. On the relationship between lactational performance and health: Is it yield or metabolic imbalance that causes production diseases in dairy cattle? A position paper. Livest. Prod. Sci. 83:277-308.

Kawashima, C., C. A. Montoya, Y. Masuda, E. Kaneko, M. Matsui, T. Shimizu, N. Matsunaga, K. Kida, Y. I. Miyake, M. Suzuki, and A. 
Miyamoto. 2007. Short communication: A positive relationship between the first ovulation postpartum and the increasing ratio of milk yield in the first part of lactation in dairy cows. J. Dairy Sci. 90:2279-2282.

Kennedy, J., P. Dillon, K. O'Sullivan, F. Buckley, and M. Rath. 2003. The effect of genetic merit for milk production and concentrate feeding level on the reproductive performance of HolsteinFriesian cows in a grass-based system. Anim. Sci. 76:297-308.

Knight, C. H., M. A. Alamer, A. Sorensen, I. M. Nevison, D. J. Flint, and R. G. Vernon. 2004. Metabolic safety-margins do not differ between cows of high and low genetic merit for milk production. J. Dairy Res. 71:141-153.

Kolver, E. S., and L. D. Muller. 1998. Performance and nutrient intake of high-producing Holstein cows consuming pasture or total mixed ration. J. Dairy Sci. 81:1403-1411.

Lamming, G. E., and A. O. Darwash. 1998. The use of milk progesterone profiles to characterise of subfertility in milked dairy cows. Anim. Reprod. Sci. 52:175-190.

Lean, I. J., J. C. Galland, and J. L. Scott. 1989. Relationship between fertility, peak milk yields and lactational persistency in dairy cows. Theriogenology 31:1093-1103.

Littell, R. C., P. R. Henry, and C. B. Ammerman. 1998. Statistical analysis of repeated measures data using SAS procedures. J. Anim. Sci. 76:1216-1231.

Logue, D. N., R. J. Berry, J. E. Offer, S. J. Chaplin, W. M. Crawshaw, K. A. Leach, P. J. H. Ball, and J. Bax. 1999. Consequences of "metabolic load" for lameness and disease. Pages 83-98 in Metabolic Stress in Dairy Cows. Occas. Publ. No. 24. Br. Soc. Anim. Sci., Penicuik, Midlothian, Scotland.

Lucy, M. C. 2001. Reproductive loss in high-producing dairy cattle: Where will it end? J. Dairy Sci. 84:1277-1293.

Lucy, M. C., C. R. Staples, W. W. Thatcher, P. S. Erickson, R. M. Cleale, J. L. Firkins, J. H. Clark, M. R. Murphy, and B. O. Brodie. 1992. Influence of diet composition, dry-matter intake, milk production and energy balance on time of post-partum ovulation and fertility in dairy cows. Anim. Prod. 54:323-331.
Marstorp, P., T. Anfalt, and L. Andersson. 1983. Determination of oxidised ketone bodies in milk by flow injection analysis. Anal. Chim. Acta 149:281-289.

McCullagh, P., and J. A. Nelder. 1989. Generalized Linear Models. 2nd ed. Chapman and Hall (CRC Press), New York, NY.

McDougall, S., D. A. Clark, K. L. Macmillan, and N. B. Williamson. 1995. Some effects of feeding pasture silage supplementation to pasture on the reproductive performance in lactating dairy cows. N. Z. Vet. J. 43:4-9.

Patton, J., D. A. Kenny, S. McNamara, J. F. Mee, F. P. O’Mara, M. G. Diskin, and J. J. Murphy. 2007. Relationship among milk production, energy balance, plasma analytes, and reproduction in Holstein-Friesian cows. J. Dairy Sci. 90:649-658.

Reist, M., D. K. Erdin, D. von Euw, K. M. Tschuemperlin, H. Leuenberger, C. Delavaud, Y. Chilliard, H. M. Hammon, N. Kuenzi, and J. W. Blum. 2003. Concentrate feeding strategy in lactating dairy cows: Metabolic and endocrine changes with emphasis on leptin. J. Dairy Sci. 86:1690-1706.

Standing Committee on Agriculture. 1990. Feeding Standards for Australian Livestock: Ruminants. CSIRO Publications, Collingwood, Victoria, Australia.

Snijders, S. E., P. G. Dillon, K. J. O'Farrell, M. D. Diskin, A. R. G. Wylie, D. O'Callaghan, M. Rath, and M. P. Boland. 2001. Genetic merit for milk production and reproductive success in dairy cows. Anim. Reprod. Sci. 65:17-31.

Spicer, L. J., W. B. Tucker, and G. D. Adams. 1990. Insulin-like growth factor-I in dairy cows: Relationships among energy balance, body condition, ovarian activity, and estrous behaviour. J. Dairy Sci. 73:929-937.

Sutter, F., and D. E. Beever. 2000. Energy and nitrogen metabolism in Holstein-Friesian cows during early lactation. Anim. Sci. 70:503-514.

Veerkamp, R. F., B. Beerda, and T. van der Lende. 2003. Effects of genetic selection for milk yield on energy balance, levels of hormones, and metabolites in lactating cattle, and possible links to reduced fertility. Livest. Prod. Sci. 83:257-275. 